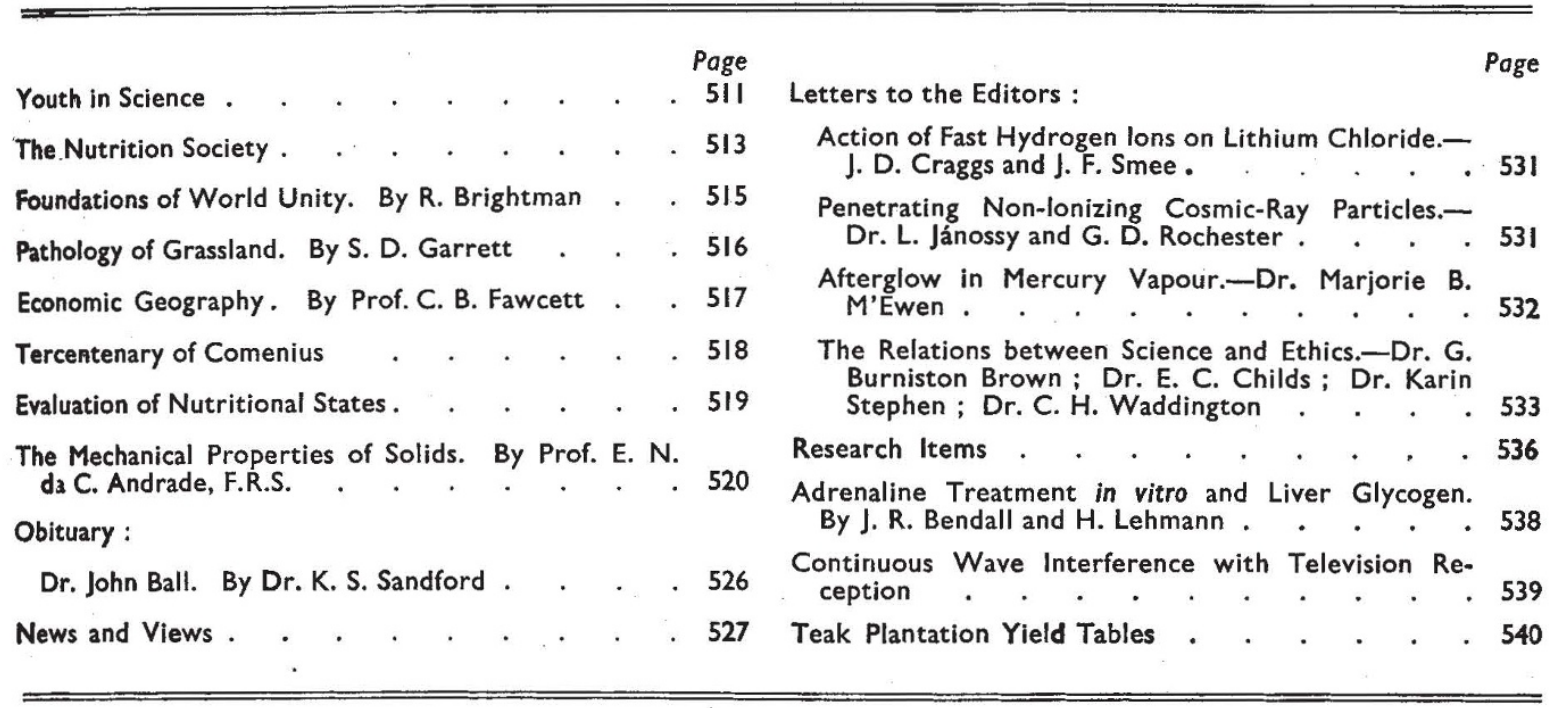

\title{
YOUTH IN SCIENCE
}

$\mathrm{O}^{\mathrm{N}}$ October 11, five thousand young men and women, representing twenty nations, met at an International Youth Rally for Victory in London. On October 13, Lord Croft, Joint Parlia. mentary Under-Secretary of State for War, spoke of the necessity of giving youth a bigger place in defence plans. The Times of October 13, commenting on the Rally, pointed out that "at the same time [the Rally was] a particular reminder to the young people in this country of the urgency of the present situation and the weight of their responsibility".

These pronouncements are a sign of the times, and all have been inspired by the seriousness of the War in which all of us are involved to a greater or less degree. We agree with The Times that youth has a tremendous responsibility to-day, and with Lord Croft that youth deserves a bigger part in our defence plans. But this touches only the fringe of a problem of major importance, touching it as it does in a time of emergency and therefore necessity; but the problem itself dates back far into history and is as deeply rooted as any other human problem. It is the problem of fitting youth, not in spite of its youthfulness but because of it, into all schemes concerned with human welfare and progress.

The very remark of The Times that the Rally served as a "particular reminder to young people in this country" indicates an attitude towards youth which for generations has been all too prevalent-that of giving the younger generation a kind of inferior distinctiveness. The majority of the younger people in this, or any other country, need no more reminding of the gravity of the world situation than the majority of the older generation. - It is because of their intelligent awareness that the Rally was held, through their own initiative ; it was not organized by their older colleagues because the latter thought youth needed telling. Youth spoke for itself.

This was clearly realized by $\mathrm{Mr}$. Bevin, who opened the meeting and who emphasized that the Rally pointed the way for a more imaginative understanding of the capabilities and aspirations of youth both by leaders of youth organizations and by the political parties. This might well be extended to cover all organizations, including those of the sciences.

The fact that the problems of youth are almost as old as the hills is beside the point. They have always complained of a sense of frustration, of being domineered by those of more mature years, sometimes of being ignored and even of being used as rungs in the ladder to fame by those in authority over them. Their complaints have often proved well founded, but seldom have they been dealt with effectively. The reasons for it are legion, and are sometimes due to thoughtlessness, but sometimes to regrettable arrogance, self-seeking or even selfishness on the part of their older colleagues. Gone are the days when any clear-thinking layman or 
more important still, psychologist would subscribe to the view that youth is synonymous with irresponsibility, and that the main characteristic of any man of responsibility must be experience. Experience is, of course, of the utmost importance provided that the person who has had it also has the intelligence and imagination to profit by it. But so often this is not the case. Furthermore, with long-drawn-out experience too often goes susceptibility to hide-bound tradition, loss of initiative and imagination, self-aggrandizement on the basis of past achievements and sometimes antipathy to growing youth, who still have those qualities coupled with an emotion peculiar to themselves.

To the older in years may be said "This was, this is, your world"; to youth "This is, this will be, your world". Whose is the greatest responsibility? We see little difference; but too often a distinction is made, to the detriment of youth. More collaboration is needed, thus giving greater encouragement to them. This can best be done by giving them a greater share of responsibility in all walks of life, including that of science, giving them greater representation on organizing, executive, administrative and even advisory bodies.

These questions were raised by several speakers at the recent Conference on Science and World Order, and it is to be hcreu that the points made will receive the serious consideration they deserve. Dr. J. E. D. Swann pleaded for a greater utilization of youthful men of science in the war effort and incisively criticized the inefficient utilization of scientific workers in the war effort.

Mr. D. P. Riley pleaded eloquently for the younger generation of scientific workers. "There should be more democracy in science. There should be a place for younger scientists in the councils of scientific planning, in the laboratories and factories themselves, and on national and international committees or commissions. Young scientists, by virtue of their very youth, are endowed with energy, initiative and enthusiasm. They bring a new point of view, that of the younger generation, to bear. Their scientific training has been based, not on the conceptions of nineteenthcentury mechanistic physics but on twentiethcentury dialectical theories, in which the interrelation of the various sciences is continually emphasized. Nowadays a chemist must also be a physicist, and a physicist an engineer, and the younger scientists have been trained from the outset in full knowledge of the diverse and powerful modes of attack on any scientific problem. The need for startling ingenuity, for completely new methods, and above all for quick thinking, is very necessary in war-time. More important than all these considerations is the fact that the humbler scientific workers can put forward the point of view of the man actually on the job-actually at the laboratory bench; actually at the production point of scientific discovery.

"The wisdom and conservatism of age and experience could thus be tempered with the effervescence and radicalism of youth. Any tendency on the part of youth to sublime overconfidence would soon be gently and firmly dealt with by their more experienced colleagues. But give youth its chance to help, and not only always at the bottom, but sometimes, dare I say it, almost at the top?

"Let youth as an essential supplement to present official plans put into direct contact with each other rank-and-file scientists in similar fields of science but working in different countries. Let personal contact be established as widely as possible. It would also serve as a valuable basis for international understanding on the cultural level after the War.

"Concerning the peace-time planning of research, it cannot be too often stressed that international co-operation is its very life-blood. In peace-time a greatly increased exchange of younger scientists between the nations is desirable. It is not sufficient to rely on private philanthropy to achieve this, as is largely the case at present, but State funds should be made generously available. These men and women would give to the foreign laboratories in which they would work the different outlook of their home training. They would bring with them different aspects of technique and approach. They would, conversely, learn and take back home with them an understanding of the methods used abroad. All this should occur during the formative years of their lives. Parochialism in science does exist and must be combated ; this is one way of doing so."

Mrs. S. Neville-Rolfe forcibly pressed before the Conference the same argument, especially from the biological and psychological points of view.

"It is recognized already in military circles (though not always practised) that those trained and experienced in the War of 1914-18 are not the best improvisors of strategy and tactics for a war of dive-bombers and tanks. This principle applies even more strongly to questions which affect the development of man himself.

"The emotionally immature, belonging to a previous generation, with a background of traditional dogma as religion, of laissez-faire as social economics, of philanthropic charity as good citizenship, and an idea of the 'equality of man' which ignores biological evidence, are not qualified to govern, or to lead youth in the present world crisis; yet it is they who are in control to-day. 
The old in experience and young in mind have ever boen outstanding leaders, but the old in mind and years are unable to grasp the new problems or to relate new knowledge to spiritual values. They fear youth and from a mistaken sense of duty they continue to bear burdens beyond their years, and are barring advance.

"It is vital to reach the younger generation, the parents of the future in service and civil life, and gain their intellectual interest and emotional drive behind the idea that man may control and direct to the service of man the forces that he has set in motion. Experience is needed, but so are drive, a new outlook, and faith in man's destiny."

To this must be added the all-important quality of leadership-a character which is not based on experience but is the outcome chiefly of initiative, imagination, determination and faith, and therefore a character no more the prerogative of the older generations than of any others. When a youth shows ability to lead, let him lead. Those of mature age might well offer him the benefit of their longer experience and guide and advise him ; but often they ignore him, and sometimes also they usurp his leadership once he has shown the way.

The President of the British Association, intervening after Mr. Riley's remarks at the Conference, expressed his sympathy with the younger scientific investigators; but there are some in authority who do not attempt to exercise such sympathy, at any rate in a practical form. Furthermore, many young men of science ask for more than sympathy ; they justly demand more practical recognition as men of science in their own right and not merely as scientific assistants. By keeping them as subordinates until middle age they often lose their capacity and desire for responsibility and initiative; they are sapped of their self-confidence. The President also pointed out that so far as the Division for the Social and Industrial Relations of Science is concerned, youth has played an im- portant part in its development. This is as it should be, especially since the Division itself is a youth. So now let the older institutions and societies and other research organizations follow this example and admit youth to their council chambers. A certain amount of balanced and controlled rejuvenation would not come amiss.

In his message to the International Youth Rally, the Prime Minister, referring to present-day needs, told youth that their place is still in the forefront of battle. H.M. the King, on the other hand, looking to the future, emphasized the gravity of the tasks which the years of reconstruction will lay upon the shoulders of youth. The two go together; they are inseparable. So also should youthful and older men of science march together, their individual status being acknowledged on grounds of scientific achievement and of intellectual, not chronological, age. Youth has a case; at present much of youth is being penalized. Until that unfair imputation is removed (and now is the time to do it), unity of purpose and team work can never be fully developed.

As pointed out in Nature of October 11, p. 427 :

"It seems well worth while investigating how to bring about the necessary unity of feeling, and to arouse sufficient enthusiasm among people agreed intellectually upon the work to be done in order to enable them to.pull together as a team. Co-opting more of the younger men in the counsels of science will undoubtedly help much towards this badly needed unity. At present some of the more progressive men of science feel keenly the neglect of their services, especially when older authorities are complaining of having too much to do, too many committees to attend, etc. Once this feeling almost of frustration is eliminated, and younger men are given their rightful place in the advancement of science, a closer unity of feeling. will be established."

\section{THE NUTRITION SOCIETY}

\begin{abstract}
A NEW scientific society devoted to the study of nutrition, the Nutrition Society, has just come into existence (see NATURE of October 11, p. 433), and an account of its first meeting appears on p. 519 of this issue. Nutritional thought in Great Britain has so far centred around the Biochemical and Physiological Societies, and in recent years the Nutrition Panel of the Society of
\end{abstract}

Chemical Industry has done much to foster interest in food problems. Admirable as these facilities were, they could not keep pace with the increasing scope of nutritional science which now also embraces agriculture, clinical study, practical dietetics and sociological problems. The new Society, while in no sense competing with existing ones, will provide a common meeting-ground 